\title{
CORRELATION OF TROPONIN-I WITH ANGIOGRAPHIC PROFILE IN PATIENTS OF UNSTABLE ANGINA
}

\author{
AKTERUZZAMAN M ${ }^{1}$, RAHMAN A ${ }^{2}$, RAHMAN A ${ }^{3}$,MIAH MNA ${ }^{4}$, HAQUE J ${ }^{5}$ RAHMAN A
}

\begin{abstract}
:
Objective: The study was intended to determine the angiographic profile (severity, site and type of lesion) based on the level of cardiac Troponin-I in patients of unstable angina.

Methods: The present cross-sectional study was conducted in the Department of Cardiology, Sir Salimullah Medical College Mitford Hospital (SSMCH). Data were collected at Ibrahim Cardiac Hospital \& Research Institute and SSMCH. A total of 81 patients of unstable angina were selected over a period of one year. Based on the level of cardiac Troponin-I at admission, the patients were divided into high risk (TroponinI level $0.06-0.6)$ and low-risk (O - <0.06) groups. Thus 47patients fell into high risk group (Group-I) and 34 patients into low-risk group (Group-II). The angiographic characteristics of the two groups of patients were then compared.
\end{abstract}

Result: Over three-quarter (77\%) of the patients in Group-I had significant and 23\% insignificant \& normal coronary lesions compared to $26 \%$ and $74 \%$ respectively in Group-II. Significant stenosis was commonly observed in Group-I than that in Group-II $(p<0.001)$. Number of vessels involved like single vessel (SVD), double vessel (DVD) and triple vessel diseases and (TVD) were higher in Group-I compared to Group-II (30\% vs. 20\%; 34\% vs. 3\% and 12\% vs. 3\%, $p=<.001$ ). A site of lesions in LAD were compared between the study groups, proximal and mid lesions were found significantly higher in Group-I than those in Group-II (45\% vs. 9\%, $p<0.001$ and 49\% vs. 18\%, $p<0.001$ respectively), while distal lesion was almost identically distributed between groups (5\% vs. $6 \%, p=0.455)$. A site of lesions were compared between the study groups, proximal and mid lesions were found significantly higher in Group-I than those in Group-II (66\% vs. 9\%, $p<0.001$ and $51 \%$ vs. 12\%, $p<0.001$ respectively), while distal lesion was almost identically distributed between groups (21\% vs. $17 \%, p=0.455)$. A significantly higher proportion of patients in Group-I exhibited Type-Blesion than that in Group-II (30\% vs. 3.0\%, $p=0.005$ ), while Type-C lesion was considerably higher in the former group than that in the latter group (47\% vs. $14 \%, p=0.005)$ and Type-A lesion was higher in the group-II than group-I(20\% vs. $8 \%, p=0.117)$. Majority (77\%) of the patients who developed significant coronary artery lesion had raised cTnI compared to $24 \%$ of the patients who did not develop significant lesion $(p<0.001)$. The chance of having significant lesion in patients with high normal cTnI was 9 times higher than that in patients with low normal cTnI.

Conclusion: Patients of unstable angina with raised serum Troponin-I had more severe coronary lesions (in terms of number of vessels significantly affected and site and type of lesions) than those with low serum Troponin-I.

Key words: Tropnin-I, angiographic profile, low-risk patients and high-risk patients

\section{Introduction :}

Unstable angina is very common and often quite serious; it is responsible for more than 750,000 hospitalizations annually in the United States ${ }^{1}$ and thus ranks among the most frequent causes of hospitalization in this country. More than 70,000 of these hospitalized patients develop myocardial infarction ${ }^{2}$ and some die suddenly ${ }^{3}$. In Bangladesh, atherosclerotic disease is increasing gradually. National data on incidence and mortality of coronary heart disease are few in Bangladesh. The prevalence

1. Assistant Registrar Department of Cardiology, Sir Salimullah Medical College Mitford Hospital, Dhaka.

2. Department of Cardiology, Sir Salimullah Medical College Mitford Hospital, Dhaka.

3. Registrar, Department of Neurology, Sir Salimullah Medical College Mitford Hospital, Dhaka .

4. Assistant Professor, Department of Medicine, Sir Salimullah Medical College, Dhaka.

5. Associate Professor, Department of Cardiology, Sir Salimullah Medical College, Dhaka.

6. Assistant Professor, Department of Cardiology, Sir Salimullah Medical College Mitford Hospital, Dhaka

Bangladesh J Medicine 2013; 24 : 5-9 
of coronary heart disease was estimated as 3.3/1000 in 1976 and 17.2/1000 in 1986 indicating 5 folds increase of the disease in 10 years ${ }^{4}$. Since the unstable coronary artery disease population is heterogeneous both regarding the severity of the underlying coronary artery disease and prognosis 5,6 early risk stratification is essential ${ }^{7}$. The pathophysiologic mechanism involve rupture or erosion of atherosclerotic plugs, with activation of platelets and of the clotting system followed by local thrombus formation 8,9 . Coronary arteriographic examinations have revealed that rapid progression of coronary stenosis often precedes the development of unstable angina ${ }^{10}$. This stenosis is frequently caused by eccentric, irregular lesion 11 often associated with filling defects thought to be caused by coronary thrombi ${ }^{12}$. Minor myocardial injury is detected in $20-40 \%$ of patients with unstable angina by the measurement of serum troponin-T or troponinI, but rarely by measurement of serum creatine kinase ${ }^{13,14}$. Thus the introduction of cardiac troponinI (cTn-I) into daily routine practice allows for highly accurate, sensitive and specific determination of myocardial injury in patients with unstable angina. Any increase in these markers implies extent of myocardial injury and an adverse outcome for these patients, with increased risk of death ${ }^{14}$.

The serum levels of both cardiac troponin-I (cTnI) and cardiac troponin-T in patients with clinically unstable angina and result showed patients with elevated troponin concentrations had more type B2 or C lesions with similar sensitivity ${ }^{15}$.

Patient with unstable coronary artery diseases and elevated Troponin-I or Troponin-T had more wide spread coronary artery disease than those without elevated and more often had complex lesion characteristics and visible thrombus in the culprit vesse1 16,17,18. Elevated values of serum Cardiac Troponin-I to be evenly associated with the severity and extent of coronary lesion ${ }^{19}$.

Recently a study on 50 consecutive patients of chest pain at rest with cTn-I above normal level and normal creatine-kinase and result showed elevated cTn-I and normal creatine-kinase levels have significant $\mathrm{CAD}^{20}$.

Although previous studies shows elevated troponin I and normal Creatinine kinase level predicts the prognosis and severity of coronary artery diseases in NSTEMI patients but coronary angiography has not been systematically perform and the angiographic characteristics have not been well determined in patients of unstable angina with border line raised troponin I level ${ }^{21}$.

The present study is, therefore, intended to find the correlation between border lines raised troponin I level and extent and severity of coronary artery disease in patients with unstable angina.

\section{Patients \& Methods:}

The present cross-sectional study was conducted in the Department of Cardiology, Sir Salimullah Medical College \& Mitford Hospital (SSMC MH). Data were collected at Ibrahim Cardiac Hospital \& Research Institute and SSMC MH. On the basis of inclusion and exclusion criteria, a total of 81 patients of unstable angina were selected over a period of one year (Sep2009-Aug2010). Based on the level of cardiac Troponin-I at and 8 hours after admission, the patients were divided into high normal (Troponin-I level $0.06-0.6)$ and low-normal $(0-<0.06)$ groups. Thus 47 patients fell into high normal group (GroupI) and 34 patients into low-normal group (Group-II). The angiographic characteristics of the two groups of patients were then compared.

\section{Results and observations:}

The present study was intended to determine cardiac Troponin-I at admission and 8 hours apart, the patients were divided into high normal (Group-I, $\mathrm{n}=$ 47) and low-normal (Group-II, $\mathrm{n}=34$ ) groups. The findings obtained from data analyses are presented below: (Table 1)

Chi-square $\left(\div^{2}\right)$ test reveals that most of unstable angina occurs in patients with high Troponin-I level particularly during rest $(\mathrm{p}<0.001)$.

Table-I

Comparison of Type of unstable angina between groups.

\begin{tabular}{lccl}
\hline \multirow{2}{*}{$\begin{array}{l}\text { Type of unstable } \\
\text { angina }\end{array}$} & \multicolumn{2}{c}{ Group } & p-value \\
\cline { 2 - 3 } & $\begin{array}{c}\text { Group-I } \\
(\mathrm{n}=47)\end{array}$ & $\begin{array}{c}\text { Group-II } \\
(\mathrm{n}=34)\end{array}$ & \\
\hline Rest angina & $30(63)$ & $8(23)$ & \\
New onset angina & $5(10)$ & $14(41)$ & $<0.001$ \\
Cresendo angina & $12(25)$ & $10(29)$ & \\
Post MI angina & 0 & $2(5.8)$ & \\
\hline
\end{tabular}

Figures in the parenthesis denote corresponding percentage

More than three-quarter (77\%) of the patients in Group-I had significant lesion and 23\% insignificant and normal lesion compared to $26 \%$ and $74 \%$ respectively in Group-II ( $\mathrm{p}<0.001)$. (Table II)

\section{Table II}

Comparison of stenosis between groups

\begin{tabular}{lccc}
\hline Stenosis & \multicolumn{2}{c}{ Group } & p-value \\
\cline { 2 - 3 } & $\begin{array}{l}\text { Group-I } \\
(\mathrm{n}=47)\end{array}$ & $\begin{array}{l}\text { Group-II } \\
(\mathrm{n}=34)\end{array}$ & \\
\hline Normal $(<20 \%)$ & $6(12.8)$ & $21(62.5)$ & \\
Insignificant & $5(10.2)$ & $4(11.8)$ & $<0.001$ \\
$(20 \%-50 \%)$ & & & \\
Significant $(>50 \%)$ & $36(77)$ & $9(26)$ & \\
\hline
\end{tabular}

\#Chi-square $\left(\chi^{2}\right)$ test was employed to analyse the data; 
Number of vessels involved like single vessel (SVD), double vessel (DVD) and triple vessels (TVD) were all higher in Group-I compared to Group-II ( $p<0.001)$ (Table III)

Table-III

Comparison of no. of vessels involved between groups

\begin{tabular}{lccc}
\hline No. of vessels & \multicolumn{2}{c}{ Group } & p-value \\
\cline { 2 - 3 } involved & $\begin{array}{c}\text { Group-I } \\
(\mathrm{n}=47)\end{array}$ & $\begin{array}{c}\text { Group-II } \\
(\mathrm{n}=34)\end{array}$ & \\
\hline None & $11(23.0)$ & $25(73.0)$ & \\
SVD & $14(30)$ & $7(20.0)$ & \\
DVD & $16(34)$ & $1(3)$ & $<0.001$ \\
TVD & $6(12)$ & $1(3)$ & \\
\hline
\end{tabular}

\#Chi-square $\left(\div^{2}\right)$ Test was employed to analyse the data;

As site of lesions were compared between the study groups, proximal and mid lesions were found significantly higher in Group-I than those in GroupII $(44.68 \%$ vs. $8.82 \%, p<0.001$ and $48.93 \%$ vs. 17.64 $\%, \mathrm{p}<0.001$ respectively), while distal lesion was almost identically distributed between groups $(4.25 \%$ vs. $5.88 \%, p=0.455)$ (Table IV).

Table IV

Comparison of site of lesions in LAD between groups

\begin{tabular}{lccc}
\hline Site of lesion & \multicolumn{2}{c}{ Group } & p-value \\
\cline { 2 - 3 } in LAD & $\begin{array}{l}\text { Group-I } \\
(\mathrm{n}=47)\end{array}$ & $\begin{array}{c}\text { Group-II } \\
(\mathrm{n}=34)\end{array}$ & \\
\hline Proximal & $21(44.68 \%)$ & $3(8.82)$ & $<.001$ \\
Mid & $23(48.93 \%)$ & $6(17.64)$ & $<.001$ \\
Distal & $2(4.25 \%)$ & $2(5.88)$ & 0.455 \\
\hline
\end{tabular}

Chi-square $\left(\div^{2}\right)$ Test was employed to analyse the data;

As site of lesions were compared between the study groups, proximal and mid lesions were found significantly higher in Group-I than those in GroupII $(65 . \%$ vs. $8.8 \%, p<0.001$ and $51 \%$ vs. $11 \%$, p < 0.001 respectively), while distal lesion was almost identically distributed between groups (21\% vs. 17 $\%, p=0.455)$ (Table V).

Table V

Comparison of site of lesions between groups

\begin{tabular}{lccc}
\hline Site of lesion & \multicolumn{2}{c}{ Group } & p-value \\
\cline { 2 - 3 } & $\begin{array}{l}\text { Group-I } \\
(\mathrm{n}=47)\end{array}$ & $\begin{array}{c}\text { Group-II } \\
(\mathrm{n}=34)\end{array}$ & \\
\hline Proximal & $31(65.95)$ & $3(8.82)$ & $<.001$ \\
Mid & $24(51.06)$ & $4(11.76)$ & $<.001$ \\
Distal & $10(21.27)$ & $6(17.64)$ & 0.455 \\
\hline
\end{tabular}

Chi-square $\left(\div^{2}\right)$ Test was employed to analyse the data.
A significantly higher proportion of patients in GroupI exhibited Type-B \& Type C lesion than that in GroupII ( $\mathrm{p}<.005)$, and Type-A lesion was higher in GroupII than group- I (20\% vs8.5, p = 0.117) (Table VI)

Table VI

Comparison of type of lesion between groups

\begin{tabular}{lccc}
\hline Type of lesion* & \multicolumn{2}{c}{ Group } & p-value \\
\cline { 2 - 3 } & $\begin{array}{c}\text { Group-I } \\
(\mathrm{n}=47)\end{array}$ & $\begin{array}{c}\text { Group-II } \\
(\mathrm{n}=34)\end{array}$ & \\
Type A & $4(8.5)$ & $7(20)$ & .117 \\
Type B & $14(30)$ & $1(3)$ & $<.005$ \\
Type C & $22(47)$ & $5(14)$ & $<.005$ \\
\hline
\end{tabular}

Data were analysed using Chi-square $\left(\div^{2}\right)$ Test.

Presence of collateral circulation was observed to be significantly higher in Group-I (40.5\%) than that observed in Group-II (8.8\%) ( $p=0.002)$ (Table VII).

Table-VII

Comparison of collateral circulation between groups

\begin{tabular}{lccc}
\hline Collateral & \multicolumn{2}{c}{ Group } & p-value \\
\cline { 2 - 3 } circulation $^{\#}$ & $\begin{array}{l}\text { Group-I } \\
(\mathrm{n}=47)\end{array}$ & $\begin{array}{c}\text { Group-II } \\
(\mathrm{n}=34)\end{array}$ & \\
\hline Present & $19(40.5)$ & $3(8.8)$ & $<.002$ \\
Absent & $28(59.5)$ & $31(91.7)$ & \\
\hline
\end{tabular}

\# Data were analysed using Chi-square $\left(\div^{2}\right)$ Test.

Table VIII shows the risk of developing significant lesion in patients with raised cTnI. Majority (77\%) of the patients who developed significant coronary artery Stenosis had raised cTnI compared to $23 \%$ of the patients who did not develop significant Stenosis ( $\mathrm{p}<$ 0.001). The chance of having significant lesion in patients with raised cTnI was 9.09 times higher than that in patients with normal or Low cTnI(Table VIII)

Table-VIII

Risk of developing significant lesion in patients with raised $c T n I$

\begin{tabular}{lccc}
\hline Significant lesion $^{\#}$ & \multicolumn{2}{c}{ Group } & \begin{tabular}{c} 
Odds \\
\cline { 2 - 3 }
\end{tabular} \\
\cline { 2 - 3 } & Developed & $\begin{array}{c}\text { Not } \\
\text { Ratio* }\end{array}$ & \\
\hline Troveloped & & \\
\hline Tropnin-I (>0.06) & $36(76.59)$ & $11(23.41)$ & 9.09 \\
Troponin-II $(<0.06)$ & $9(26.47)$ & $25(73.53)$ & \\
\hline
\end{tabular}

* Risk of developing significant lesion was estimated using Odds Ratio.

\section{Discussion:}

Since the extent of myocardial injury is an important determinant of the risk of death, it is important to identify serum markers with which to predict prognosis, in order to initiate appropriate medical 
treatment and/or invasive procedures in these patients. The presence of high normal cTnI in serum is a significant prognostic indicator in patients with unstable angina. Its independent prognostic potential persists even after adjustment for independent baseline variables known to be significantly associated with an increased risk of cardiac events. The use of cTnI in the triage of patients with unstable coronary disease may identify those at greater risk for adverse cardiac events ${ }^{22}$.

The present study aimed at finding the determining the role of cTnI in assessing the extent of myocardial injury in patients with unstable angina divide the patients into high normal and low normal groups based on cTnI values. Angiographic severity was assessed in terms of significant stenosis, number of vessel involvement, type and site of lesion in major coronary arteries as well as presence of collaterals.

Our study reported that majority of the patients in the high-normal group exhibited significant lesion in LAD, RCA and LCX than that in the low normal group $(p<0.001)$. DVDs and TVDs were frequently encountered in the former group than those in the latter group $(\mathrm{p}<0.001)$. Proximal lesion demonstrated their significant presence in the high normal group than that in the low-normal group $(\mathrm{p}<.001)$ with Type$\mathrm{B}$ and Type-C lesions common in the former group. In a study majority of the patients with elevated cTnI had significant coronary artery disease, had more type C lesions, double and triple vessel disease and left main coronary artery involvement with higher mean percentage of stenosis than those in group-II thereby favouring the findings of the present study ${ }^{23}$. A previous study showed that patients with increased levels of cTn-I and normal creatinekinase levels had a higher prevalence of coronary artery stenosis > $50 \%$ compared to patients who had normal values of both markers $(80 \% \text { vs. } 27 \% \text {; } p=0.001)^{24}$, but similar to patients who had an elevation of both markers (87\% vs. $80 \% ; p=\mathrm{NS})$.

A recent study showed that a majority of patients with elevated cTn-I in the presence of normal creatine kinase levels have significant coronary artery disease. Almost half of these patients had significant CAD of at least 2 vessels and $18 \%$ had 3 -vessel disease ${ }^{20}$. These results are consistent with findings of the present study

In patients who were enrolled in the PURSUIT trial and who underwent in-hospital angiography, 88\% had significant CAD (any stenosis > 50\%), 6\% had mild CAD (any stenosis <50\%), and 6\% had no stenosis identified, which correlates with our data ${ }^{25}$.

However, cTn-I as a predictor of angiographic picture of the coronary arteries in patients with unstable coronary disease, has certain limitations. Although the overall prevalence of false-positive serum in the general population is low, it may be increased in patients with conditions other than acute coronary syndromes, such as sepsis, septic shock, myocarditis, heart failure, cardiac arrhythmias, renal failure, pulmonary embolism and cerebrovascular accidents ${ }^{26}$.

These findings show that high normal troponin-I level is not a spurious finding, but may actually be a marker of advanced coronary artery disease. The severity of coronary artery disease has shown in previous studies to correlate with prognosis of patients and until now our knowledge of the quantitative coronary angiographic characteristics of patients with increased cTn-I but normal creatine kinase levels has been limited.

Cardiac-specific troponins are gaining acceptance as the primary biochemical cardiac marker in patients with unstable angina. They have greater diagnostic sensitivity due to their ability to identify patients with lesser amounts of myocardial damage. Elevated levels of cTn-I convey prognostic information beyond that supplied by the clinical characteristics of the patient or the ECG at presentation. Furthermore, among patients without ST-segment elevation and normal CK-MB levels, borderline raised cTn-I concentrations identify those at an increased risk of death and are thought to represent microinfarctions that result from microemboli from an unstable plaque 27,14 .

Thus the introduction of cardiac troponin-I (cTn-I) into daily routine practice allows for highly accurate, sensitive and specific determination of myocardial injury in patients with chest pain. Any increase in these markers implies extent of myocardial injury and an adverse outcome for these patients, with increased risk of death ${ }^{14}$.

\section{Conclusion:}

In the light of the findings of the present study and discussion thereof it can be concluded that majority of the patients of unstable angina with high normal cardiac troponin-I possess significant stenosis in the coronary arteries than the patients with low normal cardiac troponin-I value. Double vessel and triple vessel disease are frequently common in the high normal cardiac troponin-I level than that in the low normal cardiac troponin-I level. A proximal lesion (which usually carries a worse prognosis) are frequently present in the high normal cardiac troponin-I level than that in the low normal cardiac troponin-I level with predominantly Type-B and TypeC lesions. Borderline elevated cTn-I level convey prognostic information beyond that supplied by the clinical characteristics of the patient or the ECG at presentation.

\section{References:}

1. National Center for Health Statistics: Vital and Health Statistics: Detailed Diagnosis and Procedures for Patients Discharged From Short Stay Hospitals. US Department of Health and Human Services, Public Health Service, Series 13, No. 90, Hyattsville, Md, 1987 
2. Julian, D.G.: The natural history of unstable angina, in Hugenholtz PG, Goldman BS (eds): Unstable Angina: Current Concepts and Management. Stuttgart, Schattauer, 1985, pp 65-70.

3. Falk, E. (1992) Why do plaques rupture? Circulation, 86, (suppl 6):III30-III42.

4. Malik, A., Islam, M.N., Zafar,A., Khan,A.K.\& Ramizuddin, M.(1987) Clinical patterns of ischemic heart diseases and its association with some known risk factors. Bangladesh Heart J, 2, 1-9.

5. Fuster, V., Badimon, L., Badimon, J.\& Chesebro, J. (1992) The pathogenesis of coronary artery disease and the acute coronary syndromes (first of two parts). N Engl J Med, 326, 242-250.

6. Butman,S.,Olson,H.\&Butman,L.(1986)Early exercise testing after stabilization of unstable angina: Correlation with coronary angiographic findings and subsequent cardiac events. Am Heart J, 111, 11-18.

7. Conti, C.R.(1993) Risk stratification in unstable angina: how to select patients who need emergency revascularization. J Card Surg, 8, 391-395.

8. Davies, M.J, Thomas, A.C., Knapman, P.A.\& Hangartner, J.R.(1986) Intramyocardial platelet aggregation in patients with unstable angina suffering sudden ischemic cardiac death. Circulation, 73,418-42

9. Falk, E. (1992) Why do plaques rupture? Circulation, 86, (suppl 6):III30-III42.

10. Moise, A., Theroux, P., Taeymans, Y., Descoings, B., Lesperance, J., Waters, D.D., Pelletier, G.B.\& Bourassa, M. (1983) Unstable angina and progression of coronary atherosclerosis. N Engl JMed, 309,685-689.

11. Ambrose,J.A.,Winters,S.L., Arora,R.R.,Eng,A., Ricco,A., Gorlin,R.\&Fuster,V.(1986) Angiographic evolution of coronary artery morphology in unstable angina. J Am Coll Cardiol, 7, 472-478.

12. Capone,G., Wolf,N., Meyer,B.\&Meister,S. (1985) Frequency of intracoronary filling defects by angiography in angina pectoris at rest. Am J Cardiol,56,1403-1406.

13. Lindahl, B., Andren, B., Ohlsson, J., Venge, P.\& Wallentin, L.( 1997) Noninvasive risk stratification in unstable coronary artery disease: exercise test and biochemical markers. FRISC Study Group. Am J Cardiol, 80, 40E-44E.

14. Antman, E.M., Tanasijevic, M.J.,Thompson, B., Schactman, M., McCabe,C.H., Cannon,C.P., Fischer, G.A., Fung, A.Y., Thompson, C., Wybenga, D.\& Braunwald, E. (1996) Cardiac-specific troponin I levels to predict the risk of mortality in patients with acute coronary syndromes. $N$ Engl J Med, 335, 1342- 1349.

15. Panteghini, M., Cuccia, C., Pagani, F., Turla, C., Bonetti, G\& Bonini, E.(2002) Coronary angiographic findings in patients with clinical unstable angina according to cardiac troponin I and T concentrations in serum. Arch Pathol Lab Med, 126,448-51.

16. Jurlander, B., Farhi, E.R., Banas, J.J, Jr, Keany, C.M.,Balu, D., Grande, D.\& Ellis, A.K. (2000) Coronary angiographic findings and troponin $\mathrm{T}$ in patients with unstable angina pectoris. Am J Cardiol, 85, 810- 814.

17. Benamer,H., Steg,P.G., Benessiano,J., Vicaut,E., Gaultier, C.J., Aubry, P., Boudvillain, O.,Sarfati,L., Brochet,E., Feldman, L.J.\& Himbert,D. (1999) Elevated Cardiac troponin I predicts a high-risk angiographic anatomy of the culprit lesion in unstable angina. Am Heart J, 137(5), 815-820.

18. Heeschen, C., Goldmann, B.U., Langenbrink, L., Matschuck,G. \&Hamm, C.W. ( 1999) Evaluation of a Rapid Whole Blood ELISA for Qualification of Troponin I in patients with acute Chest pain. Clin Chem, 45(10), 1789-1796.

19. Janorkar, S., Koning, R.,Eltchaninoff, H.,Andres, H., Lavoinne, A.\& Cribier, A.( 1999) Relation between serum cardiac troponin I values and severity of clinical, electrocardiographic and quantitative angiographic features in unstable angina Indian Heart Journal, 51(1), 31-34.

20. Gruberg, L., Sudarsky, D., Kerner, A., Hammerman, H., Kapeliovich, M.\&Beyar, R. (2008) Troponin-Positive, CKMB-Negative Acute Myocardial Infarction: Clinical, Electrocardiographic and Angiographic Characteristics. J Invasive Cardiol, 20(3), 125-128.

21. Pham, M.X., Whooley, M.A., Evans,G.T., Liu,C., Emadi,H., Tong,W., Murphy,M.C.\& Fleischmann, K.E.(2004), Prognostic value of low-level cardiac troponin-I elevations in patients without definite acute coronary syndromes, Am Heart J 148,739-742.

22. Tanasijevic, M.J., Cannon, C.P.\& Antman, E.M. (1999). The role of cardiac troponin-I (cTnI) in risk stratification of patients with unstable coronary artery disease. Clin Cardiol, 22(1), 13-16.

23. Janorkar, S., Koning, R.,Eltchaninoff, H.,Andres, H., Lavoinne, A.\& Cribier, A.( 1999) Relation between serum cardiac troponin I values and severity of clinical, electrocardiographic and quantitative angiographic features in unstable angina Indian Heart Journal, 51(1), 31-34.

24. Almeda,F.Q., Calvin, J.E., Parrillo, J.E.,Sun, F.G.\&Barron, J.T.(2001). Prevalence of angiographically significant stenosis in patients with chest pain and an elevated troponin I level and normal creatine kinase and creatine kinase-MB levels. Am J Cardiol, 87, 1286- 1289.

25. Roe, M.T., Harrington, R.A., Prosper, O.M., Pieper, K.S., Bhatt, D.L., Lincoff, A.M.\&.Simoons, M.L.(2000), For the platelet Glycoprotein IIb/IIIa in unstable angina Clinical and therapeutic profile of patients presenting with acute coronary syndromes who do not have significant coronary artery disease. Circulation, 102, 1101-1106.

26. Ammann, P., Pfisterer, M., Fehr, T.\& Rickli, H.(2004)Raised cardiac troponins B Med J,328,10281029.

27. Braunwald, E., Antman, E.M., Beasley, J.W., Califf, R.M., Cheitlin, M.D., Hochman, J.S., Jones, R.H., Keveiakes,D., Kupersmith,J.,Levin,T.N.\& Pepine,C.J.( 2000) ACC/AHA Guidelines for the Management of Patients With Unstable Angina and Non-ST-Segment Elevation Myocardial Infarction.Circulation, 102(10), 1193- 1209. 